\title{
Alginate-Derived Elicitors Enhance $\beta$-Glucan Content and Antioxidant Activities in Culinary and Medicinal Mushroom, Sparassis latifolia
}

\author{
Yong-Woon Kim ${ }^{1,+}$, Yuanzheng Wu ${ }^{2,+}$, Moon-Hee Choi ${ }^{1}$, Hyun-Jae Shin ${ }^{1, * \mathbb{D}}$ and Jishun Li ${ }^{2}$ \\ 1 Department of Biochemical and Polymer Engineering, Chosun University, Gwangju 61452, Korea; \\ ywkim1205@naver.com (Y.-W.K.); aamoony1222@naver.com (M.-H.C.) \\ 2 Shandong Provincial Key Laboratory of Applied Microbiology, Ecology Institute, Qilu University of \\ Technology (Shandong Academy of Sciences), Jinan 250103, China; wuyzh@sdas.org (Y.W.); \\ yewu2@sdas.org (J.L.) \\ * Correspondence: shinhj@chosun.ac.kr; Tel.: +82-62-230-7518 \\ + These authors contributed equally to this work.
}

Received: 9 June 2020; Accepted: 24 June 2020; Published: 25 June 2020

\begin{abstract}
This study aimed to investigate the elicitation effects of alginate oligosaccharides extracted from brown algae (Sargassum species) on $\beta$-glucan production in cauliflower mushroom (Sparassis latifolia). Sodium alginate was refined from Sargassum fulvellum, S. fusiforme, and S. horneri, and characterized by proton nuclear magnetic resonance spectroscopy $\left({ }^{1} \mathrm{H} \mathrm{NMR}\right)$, resulting mannuronic acid to guluronic acid (M/G) rationes from 0.64 to 1.38. Three oligosaccharide fractions, ethanol fraction $(\mathrm{EF})$, solid fraction $(\mathrm{SF})$, and liquid fraction (LF), were prepared by acid hydrolysis and analyzed by Fourier transform infrared (FT-IR) spectra and high-performance anion-exchange chromatography with a pulsed amperometric detector (HPAEC-PAD). The samples of $S$. fusiforme resulted in the highest hydrolysate in SF and the lowest in LF, which was consistent with its highest $\mathrm{M} / \mathrm{G}$ ratio. The SF of $S$. fusiforme and LF of S. horneri were chosen for elicitation on S. latifolia, yielding the highest $\beta$-glucan contents of $56.01 \pm 3.45 \%$ and $59.74 \pm 4.49 \%$ in the stalk, respectively. Total polyphenol content (TPC) and antioxidant activities (2,2'-Azino-bis(3-ethylbenzthiazoline-6-sulfonic acid) (ABTS) radical scavenging and Superoxide dismutase (SOD)-like activity) of aqueous extracts of $S$. latifolia were greatly stimulated by alginate elicitation. These results demonstrate that alginate oligosaccharides extracted from brown algae may be useful as an elicitor to enhance the nutritional value of mushrooms.
\end{abstract}

Keywords: Alginate; $\beta$-glucan; oligosaccharides; elicitation; Sargassum species; Sparassis latifolia; polyphenol; antioxidant

\section{Introduction}

Mushrooms have been recognized as medicine sources and functional foods since ancient times owing to their bioactive compounds and diverse health benefits [1]. Cauliflower mushrooms, species of Sparassis Fr., are culinary and medicinal mushrooms that primarily, but not exclusively, grow on the stumps of coniferous trees and are widely distributed throughout northern temperate forests [2]. The Asian Sparassis isolate was originally known as S. crispa, until morphological and molecular studies redefined it as S. latifolia [3,4]. Recently this mushroom has become cultivable in Japan and Korea using conifers [5]. The fruiting bodies of S. crispa and S. latifolia exhibit excellent effects for enhancing cytokine synthesis and preventing human diseases, such as gastric ulceration, oesophageal cancer, hypertension, and diabetes. Such effects are attributable to different compounds including polysaccharides, terpenoids, phenolic compounds, and glycoproteins [6-8]. 
As major constituents of fungal cell walls, $\beta$-glucans are present in all mushroom species and play important roles in their beneficial properties for human health [9]. Previous studies described a wide range of mushroom $\beta$-glucans with different structures, such as linear 1-3- $\beta$-glucans isolated from Poria cocos, linear 1-6- $\beta$-glucans from Agaricus spp., 6-branched 1,3- $\beta$-glucans from Lentinus edodes (designated lentinan) and Grifola frondosa (designated grifolan), and 3-branched 1,6- $\beta$-glucans from Sarcodon aspratus [10-12]. Among most studied fungal glucans, 6-branched 1,3- $\beta$-glucans were reported to be efficient as biological response modifiers (BRM) for the treatment of cancer and infectious diseases [13]. Sparassis species contain considerably higher contents of $\beta$-glucan than other mushrooms, up to $43.6 \%$ of dry weight in the fruiting bodies of $S$. crispa $[14,15]$. The primary structure of $\beta$-glucan isolated from $S$. crispa was 6-branched 1,3- $\beta$-glucan with one branch in every third main-chain unit, showing high water solubility and an estimated molecular weight of ca. $510 \mathrm{kDa}$ [16,17]. Extraction and purification of $\beta$-glucans from mushroom mycelia and fruiting bodies have been established [18,19]. However, there are few studies about the enhancement of $\beta$-glucan contents in mushrooms.

To enhance the production of desirable compounds in plants or microorganisms, elicitation has been employed using biotic or abiotic elicitors to stimulate the accumulation of secondary metabolites [20,21]. For example, physical elicitation and enzyme treatments have been exploited for the growth enhancement and promotion of $\beta$-glucan contents in S. latifolia [22,23]. Alginate is a biotic elicitor that has been demonstrated to provide induced plant defense against pathogens, tolerance improvement to environmental stresses such as drought and salinity, and growth enhancement in Eucomis autumnalis, Vitis vinifera, Phoenix dactylifera, and Olea europaea [24-27]. Chemically, alginate is a linear copolymer consisting of homopolymeric blocks of residues of (1-4)-linked $\beta$-D-mannuronate (M) and its C-5 epimer $\alpha$-L-guluronate $(G)$, covalently linked together in different sequences [28]. As a biocompatible and immunogenic polysaccharide, alginate can be extracted from brown algae such as Ecklonia spp., Laminaria spp., or Sargassum spp. [29]

In this study, the physicochemical characteristics of alginate oligosaccharides extracted from Sargassum species from Korea and the enhancement of $\beta$-glucan content in S. latifolia by alginate elicitation were investigated. To the best of our knowledge, there has been no prior attempt to investigate alginate-derived elicitors for enhancement of $\beta$-glucan synthesis in mushrooms.

\section{Materials and Methods}

\subsection{Collection of Marine Brown Algae}

Three brown algae of Sargassum species were collected from the Korean coast. S. fulvellum (Turner) C. Agardh was collected in March 2017 at Jindo ( $\left.34^{\circ} 22^{\prime} 18.0^{\prime \prime} \mathrm{N}, 126^{\circ} 08^{\prime} 09.4^{\prime \prime} \mathrm{E}\right)$, S. fusiforme (Harvey) Setchell was harvested in July 2017 at Wando $\left(34^{\circ} 20^{\prime} 11.8^{\prime \prime} \mathrm{N}, 126^{\circ} 48^{\prime} 54.6^{\prime \prime} \mathrm{E}\right)$, and S. horneri (Turner)

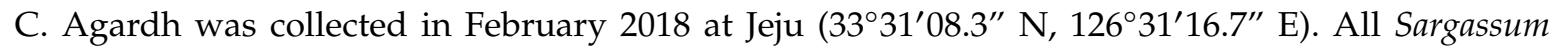
samples were cleaned by washed in distilled water to remove sand and excess salt. Samples were then oven dried at $60^{\circ} \mathrm{C}$. The samples were stored in plastic bags at room temperature $\left(25^{\circ} \mathrm{C}\right)$ until alginate extraction.

\subsection{Extraction of Sodium Alginate}

Sodium alginate was extracted as described by Davis et al. [30] In brief, $25 \mathrm{~g}$ of Sargassum samples were soaked in $800 \mathrm{~mL}$ of $2 \%$ formaldehyde for $24 \mathrm{~h}$ at room temperature, washed with distilled water, added to $800 \mathrm{~mL}$ of $0.2 \mathrm{M} \mathrm{HCl}$, and left for $24 \mathrm{~h}$. The samples were then washed with distilled water before extraction with $2 \%$ sodium carbonate $\left(\mathrm{Na}_{2} \mathrm{CO}_{3}\right)$ for $3 \mathrm{~h}$ at $100{ }^{\circ} \mathrm{C}$. The filtered extract was centrifuged $\left(10,000 \mathrm{rpm}, 30 \mathrm{~min}, 4^{\circ} \mathrm{C}\right)$ and the supernatant was precipitated with 3 volumes of $95 \%$ ethanol. The precipitate was washed with acetone and dried at $60^{\circ} \mathrm{C}$. 


\subsection{Preparation of Oligosaccharide Fractions}

Oligosaccharide separation from sodium alginate was performed as described by Asilonu et al. [31] This method gave three oligosaccharide fractions instead of two fractions from sodium alginate. In brief, $10 \mathrm{~g}$ of sodium alginate samples were acid hydrolyzed with $1 \mathrm{~L}$ of $0.3 \mathrm{M} \mathrm{HCl}$ in an autoclave at 121 ${ }^{\circ} \mathrm{C}$ for $1 \mathrm{~h}$. The suspension was quickly cooled using ice water and neutralized with $\mathrm{NaOH}$. Sodium chloride $(\mathrm{NaCl})$ was added to a final concentration of $0.5 \%(w / v)$, and the solution mixture precipitated with 2 volumes of $95 \%$ ethanol and centrifuged $\left(4000 \mathrm{rpm}, 30 \mathrm{~min}, 4^{\circ} \mathrm{C}\right)$. The supernatant was marked as ethanol fraction (EF). The precipitate was then washed with distilled water, centrifuged again, dissolved in distilled water, and adjusted to $\mathrm{pH} 2.85$ with $1 \mathrm{M} \mathrm{HCl}$. The solid fraction (SF) and liquid fraction (LF) were separated and lyophilized. Thus, three different oligosaccharide fractions (EF, SF, and LF) were obtained for further analysis.

\subsection{Physicochemical Analysis of Oligosaccharide Fractions}

\subsubsection{Molecular Weight Analysis}

The average molecular weight $\left(M_{\mathrm{W}}\right)$ of the $\mathrm{EF}, \mathrm{LF}$, and $\mathrm{SF}$ oligosaccharide fractions was determined using an SB-803 HQ column ( $6 \mu \mathrm{m}, 8.0 \mathrm{~mm} \times 300 \mathrm{~mm}$, Shodex, Japan) and an SB-805 HQ column (13 $\mu \mathrm{m}, 8.0 \mathrm{~mm} \times 300 \mathrm{~mm}$, Shodex, Japan). A mobile phase of $0.1 \mathrm{~mol} / \mathrm{L} \mathrm{NaCl}$ solution was used after $0.22 \mu \mathrm{m}$ filtration. The flow rate was $0.5 \mathrm{~mL} / \mathrm{min}$ and analyses were performed at $50{ }^{\circ} \mathrm{C}$. The sodium alginate sample $(100 \mathrm{mg})$ was then resuspended in $10 \mathrm{~mL}$ distilled water. Molecular weights were determined by reference to a calibration curve using pullulan standards [32].

\subsubsection{H NMR Spectroscopy Analysis}

Proton nuclear magnetic resonance $\left({ }^{1} \mathrm{H}\right.$ NMR) spectroscopy was acquired on alginate solution $(1 \% w / v)$ in $\mathrm{D}_{2} \mathrm{O}$, with recordings at $80{ }^{\circ} \mathrm{C}$ using an AVANCE III HD 400 (Bruker Scientific Instruments, USA) spectrometer operating at a frequency of $400 \mathrm{MHz}$. The individual blocks of guluronic and mannuronic acids ( $F_{G}$ and $F_{M}$, respectively), the homopolymeric ( $F_{G G}$ and $F_{M M}$, respectively) blocks, and the heterogeneous $\left(F_{G M}\right.$ or $\left.F_{M G}\right)$ blocks of alginate were calculated using the areas of I, II, and III $\left(A_{I}, A_{I I}\right.$ and $A_{I I I}$, respectively) signals according to the Grasdalen [33] method and Equations (1)-(3):

$$
\begin{gathered}
F_{G}=\frac{A_{I}}{A_{I I}+A_{I I I}} \\
F_{M}=1-F_{G} \\
M / G=\frac{1-F_{G}}{F_{G}}=\frac{F_{M}}{F_{G}}
\end{gathered}
$$

The double fractions ( $F_{G M}$ and $F_{M M}$ ) were deduced by referring to Equations (4)-(6):

$$
\begin{gathered}
F_{G G}=\frac{A_{I I}}{A_{I I}+A_{I I I}} \\
F_{G M}=F_{M G}=F_{G}-F_{G G} \\
F_{M M}=F_{M}-F_{M G}
\end{gathered}
$$

\subsubsection{FT-IR Spectroscopy Analysis}

Fourier transform infrared (FT-IR) spectra were measured on a Nicolet 6700 FT-IR (Thermo Electron Co., Waltham, MA, USA). Spectra of the alginate samples in $\mathrm{KBr}$ pellets were recorded in the $4000-400 \mathrm{~cm}^{-1}$ range. 


\subsubsection{Monosaccharide Analysis}

Monosaccharide analysis for the three oligosaccharide fractions was performed as follows [34]. The first acid hydrolysis was performed in $3 \mathrm{~mL}$ of $72 \% \mathrm{H}_{2} \mathrm{SO}_{4}$ with $0.3 \mathrm{~g}$ of sample for $2 \mathrm{~h}$ at $30{ }^{\circ} \mathrm{C}$. The second hydrolysis was carried out by adding $84 \mathrm{~mL}$ of distilled water to the first hydrolysate followed by acid hydrolysis at $121^{\circ} \mathrm{C}$ for $1 \mathrm{~h}$ in an autoclave. Analysis was performed using high performance anion exchange chromatography with a pulsed amperometric detector (HPAEC-PAD, ICS-5000, Dionex Co., Sunnyvale, CA, USA) equipped with a current detector, with CarboPac PA-4 ( $250 \mathrm{~mm} \times 4 \mathrm{~mm}$, Dionex Co., USA) used as the column at room temperature. An $18 \mathrm{mM} \mathrm{NaOH}$ solution was chosen as the mobile phase with a flowrate of $1.0 \mathrm{~mL} / \mathrm{min}$.

\subsection{Cultivation of Sparassis Latifolia}

Sparassis latifolia JF02-06 was provided by Jeonnam Forest Research Institute (Naju, Korea). A sawdust-based medium was used for the cultivation of cauliflower mushrooms as adopted by Park et al. [23] Fermented sawdust of Larix kaempferi, corn, and wheat flour were mixed at a ratio of 8:1:1 $(w / w / w)$, followed by the addition of $10 \%$ aqueous solution of starch syrup and an adjustment of the moisture content to $55-60 \%$. The medium was packed in a $500 \mathrm{~mL}$ incubation bottle and sterilized at $121{ }^{\circ} \mathrm{C}$ for $90 \mathrm{~min}$. The inoculum of S. latifolia was prepared in potato dextrose broth (PDB) for 3 weeks and $10 \mathrm{~mL}$ of liquid inoculum was inoculated into each bottle. The inoculated medium was then incubated at room temperature. Cultivation was completed after 50-70 days from inoculation. When mycelium was formed in the medium, the culture was transferred to the cultivation room at a temperature of $20 \pm 2{ }^{\circ} \mathrm{C}$ and $95 \%$ humidity. Fruit-shaped fruiting bodies were formed after 1 week and then harvested after $40-45$ days.

\subsection{Elicitation by Alginate Oligosaccharide Fractions}

Two of the oligosaccharide fractions, LF and SF (each $200 \mathrm{mg} / \mathrm{L}$ in distilled water), were applied to the surface of the sawdust medium for elicitation: $12 \mathrm{~mL} /$ bottle after sterilization of the medium (first application) and $20 \mathrm{~mL} /$ bottle after transfer to the cultivation room (second application). The same volume of distilled water was used as a control group. All treatments were arranged in a completely randomized block design with four replicates. Fruiting body and stalk of S. latifolia were harvested, frozen in liquid nitrogen, and stored in a freezer at $-80^{\circ} \mathrm{C}$ until extraction and analysis.

\subsection{Assay of Glucan Content}

Content of total and $\beta$-glucans was determined by a $\beta$-glucan assay kit (Cat. No. K-YBGL, Megazyme International, Wicklow, Ireland), following the $\mathrm{H}_{2} \mathrm{SO}_{4}$ acid hydrolysis procedure by McCleary and Draga [35]. Briefly, after being milled to pass through a $1.0 \mathrm{~mm}$ screen, $100 \mathrm{mg}$ of the dried mushroom samples were added with $2 \mathrm{~mL}$ of ice-cold $12 \mathrm{M} \mathrm{H}_{2} \mathrm{SO}_{4}$, and then the mixture was stirred vigorously and incubated in an ice-cold water bath for $2 \mathrm{~h}$. Then, $12 \mathrm{~mL}$ of distilled water was added to each sample and the suspension was kept in a boiling-water bath $\left(\sim 100{ }^{\circ} \mathrm{C}\right)$ for $2 \mathrm{~h}$. After cooling to room temperature, $6 \mathrm{~mL}$ of $10 \mathrm{M} \mathrm{KOH}$ was added and the volume was adjusted to $100 \mathrm{~mL}$ with $200 \mathrm{mM}$ sodium acetate buffer (pH 5.0). After centrifugation at 12,000 rpm for $10 \mathrm{~min}$, an aliquot of the supernatant $(0.1 \mathrm{~mL})$ was mixed with $0.05 \mathrm{~mL}$ of exo-1,3- $\beta$-glucanase $(20 \mathrm{U} / \mathrm{mL})$ plus $\beta$-glucosidase $(4 \mathrm{U} / \mathrm{mL})$ and incubated at $40{ }^{\circ} \mathrm{C}$ for $60 \mathrm{~min}$. Then, the mixture was incubated at 40 ${ }^{\circ} \mathrm{C}$ for $20 \mathrm{~min}$ with $3 \mathrm{~mL}$ of glucose-oxidase/peroxidase-reagent (GOPOD). Total glucan content was evaluated by a UV-Vis spectrophotometer (S-3100, SCINCO, Seoul, Korea) at $\lambda=510 \mathrm{~nm}$ with the reagent blank.

The $\alpha$-glucan content was determined after incubation at $40{ }^{\circ} \mathrm{C}$ for $30 \mathrm{~min}$ of the suspension of $100 \mathrm{mg}$ mushroom samples in $2 \mathrm{~mL}$ of $2 \mathrm{M} \mathrm{KOH}$ with an addition of $8 \mathrm{~mL}$ of $1.2 \mathrm{M}$ sodium acetate buffer (pH 3.8) with $0.2 \mathrm{~mL}$ of amyloglucosidase $(1630 \mathrm{U} / \mathrm{mL})$ plus invertase $(500 \mathrm{U} / \mathrm{mL})$. Each sample was centrifuged at $12,000 \mathrm{rpm}$ for $10 \mathrm{~min}$, and $0.1 \mathrm{~mL}$ of the supernatant was analyzed for glucose 
by mixing with $0.1 \mathrm{~mL}$ of $200 \mathrm{mM}$ of sodium acetate buffer (pH 5.0) and $3 \mathrm{~mL}$ of GOPOD. $\alpha$-Glucan content was evaluated by a UV-Vis spectrophotometer. $\beta$-Glucan content was determined as the difference between total and $\alpha$-glucan contents.

\subsection{Determination of Total Polyphenol Content}

Total polyphenol content (TPC) of aqueous extracts of S. latifolia after alginate elicitation was determined by the modified Folin-Ciocalteu method [36]. An ramount of $0.5 \mathrm{~mL}$ of the extract was mixed with $0.5 \mathrm{~mL}$ of $0.2 \mathrm{~N}$ Folin-Ciocalteu reagent and $0.5 \mathrm{~mL}$ of $2 \%(w / v)$ sodium carbonate. The mixture was vortexed and incubated at room temperature for $30 \mathrm{~min}$. The absorbance of the mixture was measured at $\lambda=750 \mathrm{~nm}$ with a UV-Vis spectrophotometer. Total polyphenol content was expressed as of gallic acid equivalent (GAE) $\mathrm{mg} / 100 \mathrm{~g}$.

\subsection{Measurement of Antioxidant Activities}

The antioxidant activities of aqueous extracts of $S$. latifolia were evaluated by scavenging activity of 2,2'-azino-bis-3-ethylbenzothiazoline-6-sulphonic acid (ABTS) radical cation and superoxide dismutase (SOD)-like activity.

\subsubsection{Assay of ABTS Radical Scavenging Activity}

2,2'-Azino-bis(3-ethylbenzthiazoline-6-sulfonic acid) (ABTS) radical scavenging activity was measured using a modified method of Re et al. [37] The ABTS stock solution was prepared by mixing 7 $\mathrm{mM}$ ABTS with $2.45 \mathrm{mM}$ potassium persulfate and then kept in the dark for $12 \mathrm{~h}$. The stock solution was then diluted with phosphate buffered saline (PBS, pH 7.4) until absorbance reached $0.80 \pm 0.02$ at $\lambda=730 \mathrm{~nm}$ using a UV-Vis spectrophotometer. Of the extracts of S. latifolia, $0.2 \mathrm{~mL}$ was mixed with 1 $\mathrm{mL}$ of diluted ABTS solution and left for $15 \mathrm{~min}$ in the dark. ABTS radical scavenging activity (\%) was calculated as in Equation (7) as follows:

$$
\text { ABTS radical scavenging activity }(\%)=\frac{A_{0}-A_{1}}{A_{0}} \times 100,
$$

where $A_{0}$ is the absorbance of the blank sample using water, and $A_{1}$ is the absorbance of the aqueous extracts of S. latifolia.

\subsubsection{Assay of SOD-Like Activity}

Superoxide dismutase (SOD)-like activity was measured by reference using an SOD kit (Cat. No. 19160, Sigma-Aldrich, St. Louis, MO, USA) [38]. Of the aqueous extracts of S. latifolia, $20 \mu \mathrm{L}$ was mixed with $200 \mu \mathrm{L}$ of water-soluble tetrazolium salt (WST) working solution and $20 \mu \mathrm{L}$ of enzyme working solution to each well in a 96-well microplate. Then the microplate was incubated at $37^{\circ} \mathrm{C}$ for $20 \mathrm{~min}$. The absorbance of each sample was measured at $\lambda=450 \mathrm{~nm}$ using a microplate reader. The SOD-like activity (\%) was calculated as in Equation (8) as follows:

$$
\text { SOD }- \text { like activity }(\%)=\frac{(\text { Blank } 1-\text { Blank } 3)-(\text { Sample }- \text { Blank } 2)}{(\text { Blank } 1-\text { Blank } 3)} \times 100
$$

where Blank 1 is the absorbance of the water with WST working solution and enzyme working solution, Blank 2 is the absorbance of sample with WST working solution and dilution buffer, Blank 3 is the absorbance of water with WST working solution and dilution buffer, and Sample is the absorbance of the aqueous extracts of S. latifolia. 


\subsection{Statistical Analysis}

Data were analyzed using analysis of variance (ANOVA) followed by Duncan's multiple-range test $(p<0.05)$ using SPSS software (version 23, SPSS, Chicago, IL, USA). Error bars indicate the mean $\pm S D$ and different letters describe significant differences within the same application data group.

\section{Results}

\subsection{Physicochemical Properties of Alginate}

Sodium alginate was extracted and refined from three Sargassum species, namely S. fulvellum, S. fusiforme, and S. horneri. The composition of extracted alginate is summarized in Table 1 . The highest alginate yield was obtained from S. fusiforme $(37.84 \pm 0.48 \%)$, followed by $34.11 \pm 1.65 \%$ from S. horneri and $30.88 \pm 1.51 \%$ from S. fulvellum. The size of the extracted alginates was relatively high in S. fusiforme and S. fulvellum with an average $M_{\mathrm{W}}$ of 504.65 and $461.07 \mathrm{kDa}$, respectively. However, the alginate from $S$. horneri had a much lower $M_{\mathrm{W}}(138.10 \mathrm{kDa})$ than that of the other two algae. This indicates that different ranges of alginates are obtained from different Sargassum species.

Table 1. Composition of sodium alginate extracted from Sargassum species.

\begin{tabular}{ccccccccc}
\hline Species & Yield (\%) & $\mathbf{M w}(\mathbf{k D a})$ & $\mathbf{M} / \mathbf{G}$ & $\boldsymbol{F}_{\boldsymbol{M}}$ & $\boldsymbol{F}_{\boldsymbol{G}}$ & $\boldsymbol{F}_{\boldsymbol{M M}}$ & $\boldsymbol{F}_{\boldsymbol{M G}}$ & $\boldsymbol{F}_{G G}$ \\
\hline $\begin{array}{c}\text { Sargassum } \\
\text { fusiforme }\end{array}$ & $37.84 \pm 0.48$ & 504.65 & 1.38 & 0.58 & 0.42 & 0.55 & 0.03 & 0.39 \\
\hline S. fulvellum & $30.88 \pm 1.51$ & 461.07 & 0.88 & 0.47 & 0.53 & 0.43 & 0.04 & 0.49 \\
\hline S. horneri & $34.11 \pm 1.65$ & 138.10 & 0.64 & 0.39 & 0.61 & 0.30 & 0.09 & 0.52 \\
\hline
\end{tabular}

$M_{\mathrm{W}}$ : average molecular weight; $F_{M}$ : Mannuronic acid block fractions; $F_{G}$ : Guluronic acid block fractions; $F_{M M}$ : Homopolymeric mannuronic acid block fractions; $F_{M G}$ : Heterogeneous block fractions (mannuronic acid and guluronic acid); $F_{G G}$ : Homopolymeric guluronic acid block fractions.

The ratio of mannuronic acid to guluronic acid $(\mathrm{M} / \mathrm{G})$ of the structural blocks were determined by ${ }^{1} \mathrm{H}$ NMR analysis. As shown in Table 1, the M/G ratio of Sargassum species ranged from 0.64 to 1.38 , with the highest ratio of 1.38 from $S$. fusiforme and similar $\mathrm{M} / \mathrm{G}$ rationes between $\mathrm{S}$. fusiforme and S. horneri. The guluronic acid anomeric proton (G-1) occurred at 5.56-5.58 ppm (peak I), guluronic acid H-5 (G-5) occurred at 4.96-4.98 ppm (peak III), and mannuronic acid anomeric proton (M-1) and the C-5 of alternating blocks (GM-5) overlapped at 5.21-5.23 ppm (peak II), as shown in Figure 1.

The FT-IR spectrum of sodium alginate of Sargassum species is presented in Figure 2. A broad band at $3466.25 \mathrm{~cm}^{-1}$ was assigned to the hydrogen-bonded $(\mathrm{O}-\mathrm{H})$ stretching vibrations, and a weak signal at $2928.43 \mathrm{~cm}^{-1}$ was attributed to C-H stretching vibrations. The peaks at $1619.79 \mathrm{~cm}^{-1}$ and 1427.52 $\mathrm{cm}^{-1}$ were attributed to asymmetric stretching of carboxylate $\mathrm{O}-\mathrm{C}-\mathrm{O}$ vibrations. The characteristic peaks of alginate include $1096.76 \mathrm{~cm}^{-1}$ assigned to $\beta$-mannuronic acid and $1029.66 \mathrm{~cm}^{-1}$ assigned to $\alpha$-L-guluronic acid. Moreover, signals of glucuronic acid $\left(1737.01,1629.72\right.$, and $1144.66-937.31 \mathrm{~cm}^{-1}$ ) could be detected in Figure 2 (LF and EF of a,b,c). 


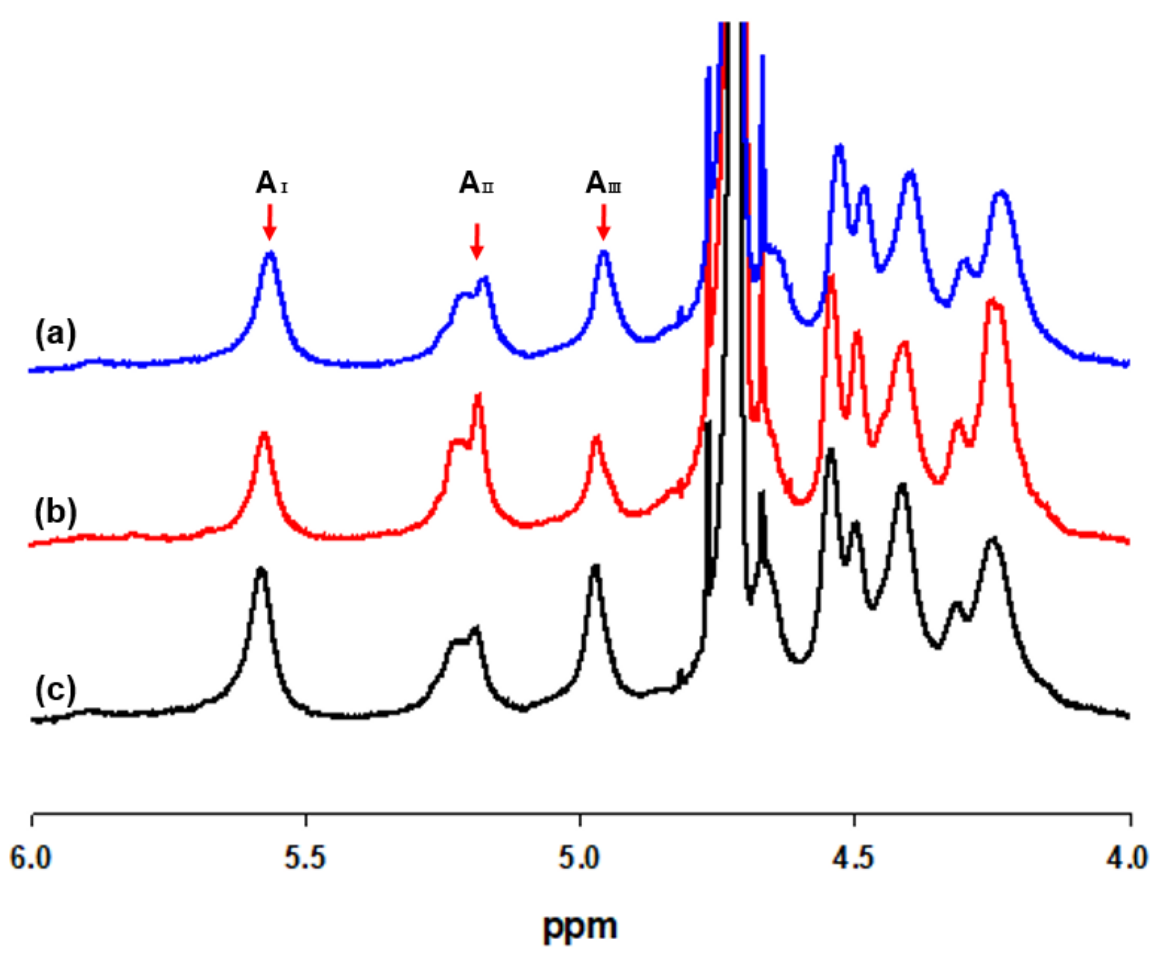

Figure 1. ${ }^{1} \mathrm{H}$ NMR spectra of sodium alginates extracted from (a) Sargassum fulvellum, (b) S. fusiforme, and (c) S. horneri ( $\mathrm{A}_{\mathrm{I}}$ : Area of guluronic acid anomeric proton peak I; $\mathrm{A}_{\mathrm{II}}$ : Area of mannuronic acid anomeric proton and the $\mathrm{C}-5$ of alternating blocks peak II; $\mathrm{A}_{\mathrm{III}}$ : Area of guluronic acid peak III).
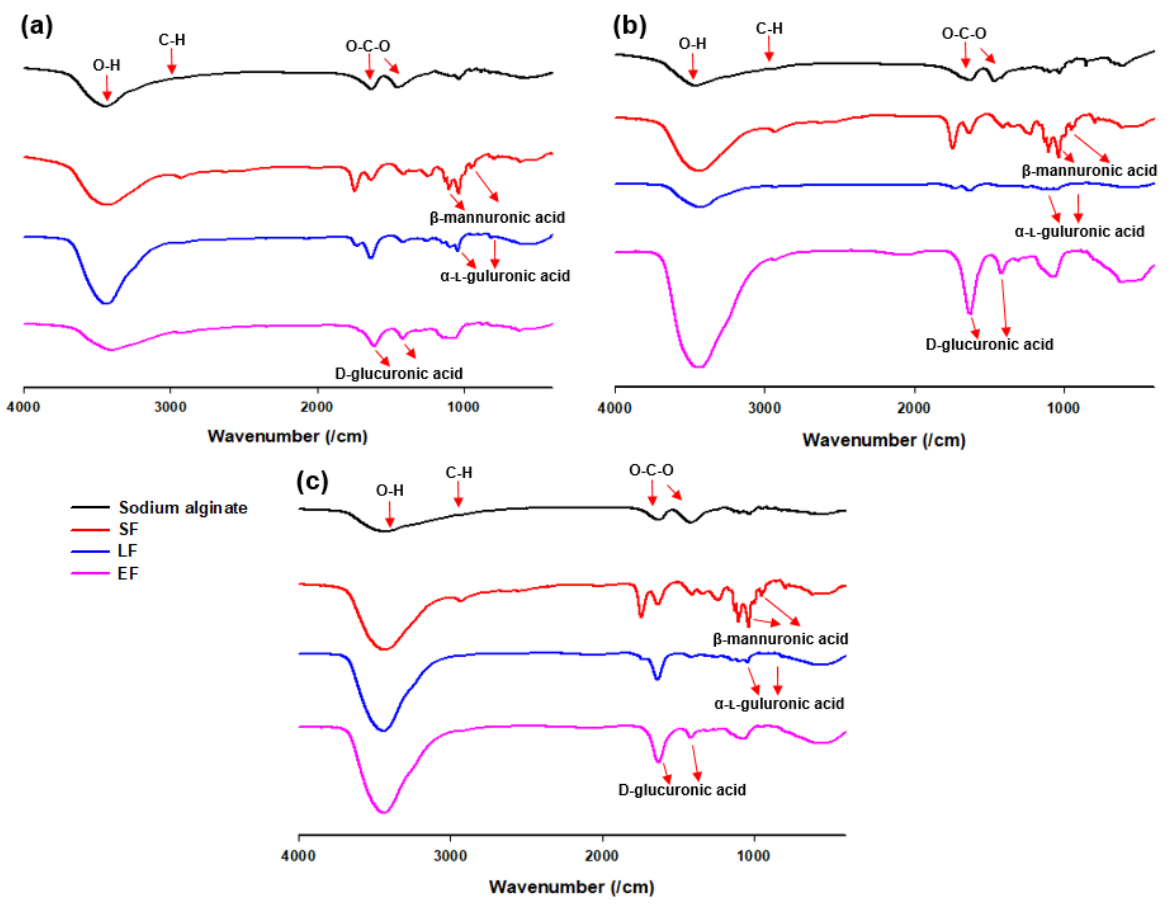

Figure 2. Fourier transform infrared (FT-IR) spectra of sodium alginate, solid fraction (SF), liquid fraction (LF), and ethanol fraction (EF) from (a) Sargassum fulvellum, (b) S. fusiforme, and (c) S. horneri.

\subsection{Oligosaccharide Analysis}

Sodium alginates extracted from Sargassum species were submitted to a two-step $\mathrm{H}_{2} \mathrm{SO}_{4}$ acid hydrolysis process to obtain partial hydrolysates for monosaccharide analysis. The block distribution of partial acid hydrolysates in EF, SF, and LF were $13.9-20.4 \%, 15.8-22.8 \%$, and $61.1-65.0 \%$, respectively. 
The block distribution of this study was compared with that of previous reports by Haug et al. and Leal et al. [39,40], as summarized in Table 2. The comparison data showed a great difference in partial hydrolysis yield according to species used for the preparation of alginate oligosaccharides. The samples of S. fusiforme showed the highest hydrolysate yields in SF and the lowest in LF among Sargassum species, which was consistent with the highest $\mathrm{M} / \mathrm{G}$ ratio of 1.38 and might be explained by the high content of polymannuronic acid and low content of polyguluronic acid. S. fulvellum and S. horneri both produced lower hydrolysate yields in SF and higher yields in LF, as indicated by their low M/G rationes. All three Sargassum species yielded similar percentages of hydrolysates in EF.

Table 2. Block distribution of sodium alginate from different species of brown algae.

\begin{tabular}{|c|c|c|c|c|c|}
\hline \multirow{2}{*}{ Species } & \multirow{2}{*}{$\mathbf{M} / \mathrm{G}$} & \multicolumn{3}{|c|}{ Partial Hydrolysis (Yields) } & \multirow{2}{*}{ Reference } \\
\hline & & EF (\%) & SF (\%) & LF (\%) & \\
\hline Sargassum fusiforme & 1.38 & 63.8 & 20.4 & 15.8 & This study \\
\hline S. fulvellum & 0.88 & 65.0 & 13.9 & 21.1 & This study \\
\hline S. horneri & 0.64 & 61.1 & 16.1 & 22.8 & This study \\
\hline Ascophyllum nodosum & 1.85 & 52 & 35 & 13 & [39] \\
\hline Chordaria flagelliformis & 0.90 & 21 & 28 & 51 & [39] \\
\hline Desmarestia aculeata & 0.85 & 27 & 23 & 50 & [39] \\
\hline Dictyosiphon foeniculaceus & 0.85 & 25 & 25 & 50 & [39] \\
\hline Fucus serratus & 1.30 & 35 & 34 & 31 & [39] \\
\hline Laminaria digitata & 1.45 & 34 & 43 & 23 & [39] \\
\hline L. hyperborea, fronds & 1.35 & 26 & 43 & 31 & [39] \\
\hline L. hyperborea, stripes & 0.65 & 25 & 15 & 60 & [39] \\
\hline Pelvetia canaliculata & 1.50 & 38 & 37 & 25 & [38] \\
\hline Pylaiella & 0.75 & 40 & 18 & 42 & [39] \\
\hline Scytosiphon lomentaria & 1.15 & 25 & 35 & 40 & [39] \\
\hline Spermatochnus paradoxus & 1.30 & 35 & 32 & 33 & [39] \\
\hline Desmarestia ligulata & 0.58 & 3.7 & 25.1 & 56.4 & [40] \\
\hline D. ligulata & 0.77 & 3.5 & 37.0 & 47.1 & [40] \\
\hline Lessonia flavicans & 1.03 & 8.5 & 41.3 & 22.2 & [40] \\
\hline
\end{tabular}

EF: Ethanol fraction of acid-hydrolyzed sodium alginate; SF: Solid fraction at $\mathrm{pH} 2.85$ (fraction enriched in polymannuronic acid); LF: Liquid fraction at $\mathrm{pH} 2.85$ (fraction enriched in polyguluronic acid).

HPAEC-PAD analysis of the $\mathrm{H}_{2} \mathrm{SO}_{4}$ hydrolysate of sodium alginate showed that monosaccharides were dominated by the weight of fucose, rhamnose, arabinose, galactose, glucose, mannose, xylose, mannuronic acid, guluronic acid, and glucuronic acid (Table 3). The major alginate contents comprised mannuronic acid and guluronic acid, as expected. The content of uronic acids was almost the same as that of $S$. turbinarioides as reported by Fenoradosoa et al. [41] The main monosaccharides of alginate from EF, SF, and LF were mannuronic acid, guluronic acid, and glucuronic acid. The size of the extracted ethanol fraction ranged from 650 to $5500 \mathrm{Da}$. 
Table 3. Monomeric carbohydrate contents from Sargassum species determined by high-performance anion-exchange chromatography with a pulsed amperometric detector (HPAEC-PAD) analysis after two-step sulfuric acid hydrolysis $\left(\mathrm{mg}^{-1} \mathrm{~g}^{-1}\right)$.

\begin{tabular}{|c|c|c|c|c|c|c|c|c|c|c|c|}
\hline Species & Fraction & Fuc & Rham & Arab & Gal & Glu & Man & Xyl & Mannu & Gulur & Glucu \\
\hline \multirow{4}{*}{$\begin{array}{l}\text { Sargassum } \\
\text { fusiforme }\end{array}$} & SA & $\begin{array}{l}26.38 \\
\pm 0.88\end{array}$ & ND & ND & $\begin{array}{c}6.21 \pm \\
0.16\end{array}$ & $\begin{array}{c}0.29 \pm \\
0.02\end{array}$ & $\begin{array}{c}7.17 \pm \\
0.25\end{array}$ & $\begin{array}{c}4.50 \pm \\
0.18\end{array}$ & $\begin{array}{l}179.64 \\
\pm 2.37\end{array}$ & $\begin{array}{l}167.57 \\
\pm 1.88\end{array}$ & $\begin{array}{c}10.67 \\
\pm 0.29\end{array}$ \\
\hline & SF & $\begin{array}{c}0.32 \pm \\
0.01\end{array}$ & ND & ND & $\begin{array}{c}0.10 \pm \\
0.01\end{array}$ & ND & ND & ND & $\begin{array}{l}54.29 \\
\pm 0.14\end{array}$ & $\begin{array}{c}13.18 \\
\pm 0.51\end{array}$ & ND \\
\hline & LF & $\begin{array}{c}1.84 \pm \\
0.03\end{array}$ & ND & ND & $\begin{array}{c}0.69 \pm \\
0.01\end{array}$ & ND & $\begin{array}{c}0.082 \\
\pm 0.04\end{array}$ & 0.35 & $\begin{array}{c}8.47 \pm \\
0.09\end{array}$ & $\begin{array}{l}107.57 \\
\pm 1.88\end{array}$ & ND \\
\hline & EF & $\begin{array}{c}7.68 \pm \\
0.10\end{array}$ & ND & ND & $\begin{array}{c}2.8 \pm \\
0.04\end{array}$ & ND & $\begin{array}{c}3.59 \pm \\
0.04\end{array}$ & $\begin{array}{c}0.87 \pm \\
0.02\end{array}$ & $\begin{array}{c}5.46 \pm \\
0.02\end{array}$ & $\begin{array}{c}11.38 \\
\pm 0.11\end{array}$ & $\begin{array}{c}6.39 \pm \\
0.06\end{array}$ \\
\hline \multirow{4}{*}{ S. fulvellum } & SA & $\begin{array}{l}24.21 \\
\pm 0.60\end{array}$ & $\begin{array}{c}0.12 \pm \\
0.01\end{array}$ & $\begin{array}{c}0.03 \pm \\
0.00\end{array}$ & $\begin{array}{r}15.07 \\
\pm 0.32\end{array}$ & $\begin{array}{c}0.35 \pm \\
0.00\end{array}$ & $\begin{array}{c}8.59 \pm \\
0.36\end{array}$ & $\begin{array}{l}4.60 \pm \\
0.05\end{array}$ & $\begin{array}{l}136.79 \\
\pm 1.82\end{array}$ & $\begin{array}{l}167.19 \\
\pm 1.10\end{array}$ & $\begin{array}{c}20.27 \\
\pm 0.22\end{array}$ \\
\hline & SF & $\begin{array}{c}0.17 \pm \\
0.00\end{array}$ & ND & ND & ND & $\begin{array}{c}0.11 \pm \\
0.00\end{array}$ & $\begin{array}{c}0.48 \pm \\
0.00\end{array}$ & $\begin{array}{c}0.05 \pm \\
0.00\end{array}$ & $\begin{array}{c}42.07 \\
\pm 2.82\end{array}$ & $\begin{array}{c}7.53 \pm \\
6.79\end{array}$ & ND \\
\hline & $\mathrm{LF}$ & $\begin{array}{c}3.88 \pm \\
0.05\end{array}$ & $\begin{array}{c}0.03 \pm \\
0.00\end{array}$ & $\begin{array}{c}0.05 \pm \\
0.00\end{array}$ & $\begin{array}{c}2.40 \pm \\
0.03\end{array}$ & $\begin{array}{c}1.77 \pm \\
0.02\end{array}$ & $\begin{array}{c}2.09 \pm \\
0.04\end{array}$ & $\begin{array}{c}1.08 \pm \\
0.03\end{array}$ & $\begin{array}{l}26.18 \\
\pm 0.77\end{array}$ & $\begin{array}{l}100.16 \\
\pm 0.54\end{array}$ & $\begin{array}{c}4.11 \pm \\
0.31\end{array}$ \\
\hline & $\mathrm{EF}$ & $\begin{array}{c}8.86 \pm \\
0.06\end{array}$ & $\begin{array}{c}0.05 \pm \\
0.00\end{array}$ & $\begin{array}{c}0.01 \pm \\
0.00\end{array}$ & $\begin{array}{c}4.96 \pm \\
0.04\end{array}$ & $\begin{array}{c}0.10 \pm \\
0.03\end{array}$ & $\begin{array}{c}4.42 \pm \\
0.04\end{array}$ & $\begin{array}{c}1.03 \pm \\
0.04\end{array}$ & $\begin{array}{c}9.11 \pm \\
0.18\end{array}$ & $\begin{array}{c}3.56 \pm \\
0.20\end{array}$ & $\begin{array}{c}4.24 \pm \\
0.05\end{array}$ \\
\hline \multirow{4}{*}{ S. horneri } & SA & $\begin{array}{l}20.14 \\
\pm 0.20\end{array}$ & ND & ND & $\begin{array}{c}13.45 \\
\pm 0.09\end{array}$ & ND & $\begin{array}{c}5.70 \pm \\
0.13\end{array}$ & $\begin{array}{c}4.40 \pm \\
0.24\end{array}$ & $\begin{array}{l}127.37 \\
\pm 0.39\end{array}$ & $\begin{array}{l}189.99 \\
\pm 0.36\end{array}$ & $\begin{array}{r}16.93 \\
\pm 0.32\end{array}$ \\
\hline & SF & $\begin{array}{c}0.24 \pm \\
0.00\end{array}$ & ND & ND & ND & $\begin{array}{c}0.19 \pm \\
0.00\end{array}$ & $\begin{array}{c}0.14 \pm \\
0.00\end{array}$ & $\begin{array}{c}0.09 \pm \\
0.00\end{array}$ & $\begin{array}{l}43.98 \\
\pm 5.70\end{array}$ & $\begin{array}{c}7.89 \pm \\
1.05\end{array}$ & ND \\
\hline & LF & $\begin{array}{c}3.26 \pm \\
0.02\end{array}$ & $\begin{array}{c}0.03 \pm \\
0.00\end{array}$ & $\begin{array}{c}0.01 \pm \\
0.00\end{array}$ & $\begin{array}{c}2.51 \pm \\
0.02\end{array}$ & $\begin{array}{c}0.16 \pm \\
0.02\end{array}$ & $\begin{array}{c}2.11 \pm \\
0.05\end{array}$ & $\begin{array}{c}0.34 \pm \\
0.02\end{array}$ & $\begin{array}{c}22.21 \\
\pm 1.08\end{array}$ & $\begin{array}{l}135.61 \\
\pm 3.18\end{array}$ & $\begin{array}{c}3.44 \pm \\
0.31\end{array}$ \\
\hline & EF & $\begin{array}{c}9.26 \pm \\
0.12\end{array}$ & $\begin{array}{c}0.08 \pm \\
0.00\end{array}$ & ND & $\begin{array}{c}6.57 \pm \\
0.04\end{array}$ & $\begin{array}{c}0.16 \pm \\
0.00\end{array}$ & $\begin{array}{c}5.52 \pm \\
0.08\end{array}$ & $\begin{array}{c}1.03 \pm \\
0.02\end{array}$ & $\begin{array}{c}11.71 \\
\pm 0.39\end{array}$ & $\begin{array}{c}4.77 \pm \\
0.76\end{array}$ & $\begin{array}{c}5.65 \pm \\
0.32\end{array}$ \\
\hline
\end{tabular}

Fuc: Fucose; Rham: Rhamnose; Arab: Arabinose; Gal: Galactose; Glu: Glucose; Man: Mannose; Xyl: Xylose; Mannu: Mannuronic acid; Gulur: Guluronic acid; Glucu: Glucuronic acid; SA: Sodium alginate; EF: Ethanol fraction; SF: Solid fraction; LF: Liquid fraction; ND: Not detected.

\subsection{Elicitation by Alginate on $\beta$-Glucan Contents}

From the results of oligosaccharide analysis of different fractions of Sargassum species, the solid fraction (SF) of S. fusiforme and liquid fraction (LF) of S. horneri were chosen as elicitors because of their high content of mannuronic acid and guluronic acid, respectively. The elicitation on Sparassis latifolia showed that SF treatment required a cultivation period of 47 days for mycelial growth, whereas LF treatment and the control group required a cultivation period of 43 days (Figure 3a). SF treatment provided higher mushroom production $(197.30 \pm 2.64 \mathrm{~g})$ than the control group $(192.04 \pm 1.58 \mathrm{~g})$, whereas LF treatment $(191.05 \pm 2.43 \mathrm{~g}$ ) showed slightly lower results than the control group (Figure $3 \mathrm{~b}$ ). However, an additional spray of SF and LF elicitors resulted in lower yields of mushroom production, and this may be caused by excessive humidity as the control group also showed a decline with the second application.

These alginate-derived elicitors presented different effects on $\beta$-glucan content in the fruiting body and stalk of $S$. latifolia. SF elicitor was more effective for $\beta$-glucan enhancement in the fruiting body, whereas LF elicitor was more effective in the stalk (Figure 3c). For the second application, both SF $(56.01 \pm 3.45 \%)$ and LF $(59.74 \pm 4.49 \%)$ treatments showed obvious high increments of $\beta$-glucan contents in the stalk compared with the control $(21.65 \%)$, which indicates that the additional spray of alginate oligosaccharide fractions apparently stimulated the $\beta$-glucan synthesis process in the stalk compared with that in the fruiting body (Figure 3d). 

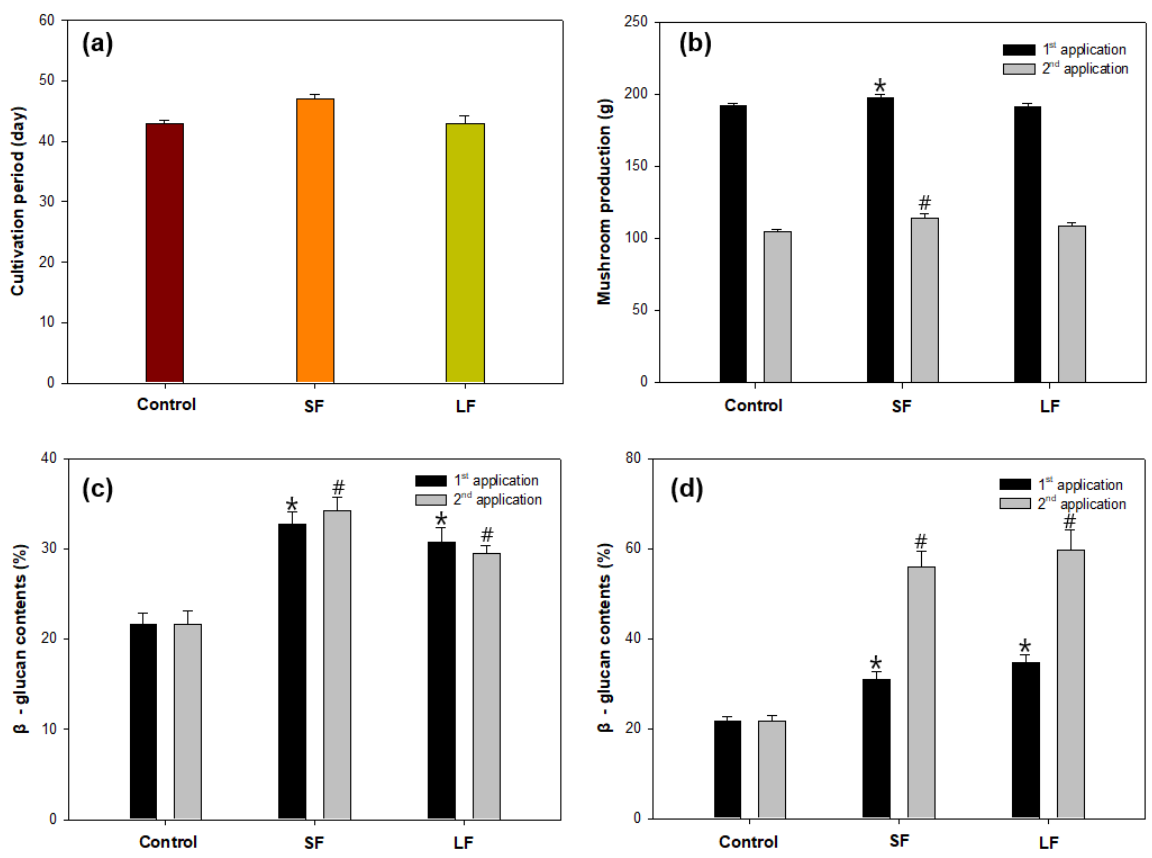

Figure 3. Elicitation of Sparassis latifolia by alginate oligosaccharide fractions on (a) cultivation period, (b) mushroom production, (c) $\beta$-glucan content of the fruiting body, and (d) $\beta$-glucan content of the stalk. SF: Solid fraction of Sargassum fusiforme; LF: Liquid fraction of S. horneri; Control: distilled water. (All data are presented as the mean $\pm \mathrm{SD}$. A $t$-test was used to compare the control and treated samples. $* p<0.05$, vs. the control in first application; $\# p<0.05$, vs. the control in second application).

\subsection{Alginate Effects on Total Polyphenol Content}

After the second application of alginate oligosaccharide fractions, total polyphenol content (TPC) in the fruit body and in the stalk of S. latifolia was determined, and gallic acid was used as standard. The TPC of the samples ranged from $140.11 \pm 6.72$ to $420.87 \pm 16.99 \mathrm{GAE} \mathrm{mg} / 100 \mathrm{~g}$ (Figure 4 ). There were significant differences in TPC $(p<0.05)$ depending on the mushroom part and treated elicitor. The TPC of stalk samples was higher than for the corresponding fruit body samples. LF treatment exhibited a higher TPC value than SF treatment, both in the fruit body and stalk samples.

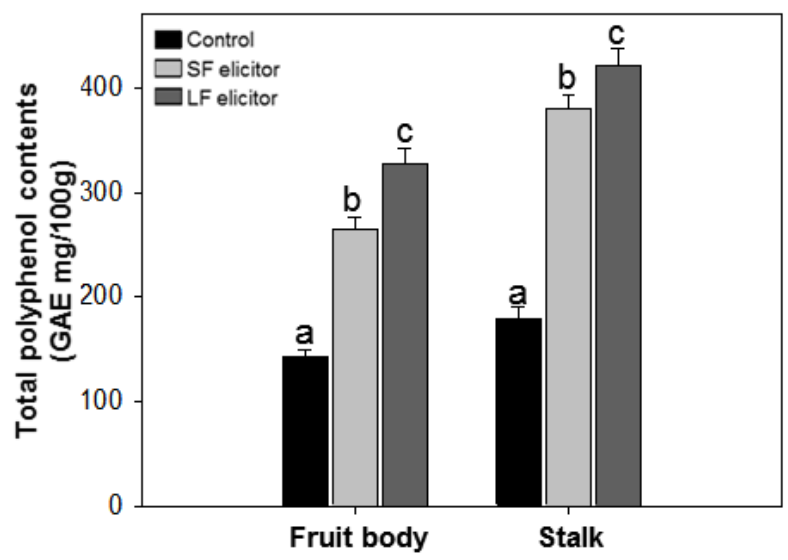

Figure 4. Total polyphenol contents of aqueous extracts of Sparassis latifolia after alginate elicitation. SF: Solid fraction of Sargassum fusiforme; LF: Liquid fraction of S. horneri; Control: distilled water. The data were analyzed using analysis of variance (ANOVA) followed by Duncan's multiple-range test $(p<$ 0.05) using SPSS software (SPSS, Chicago, IL). Error bars indicate the mean \pm SD and different letters describe greater differences within the same part of $S$. latifolia (fruit body and stalk). 


\subsection{Alginate Effects on Antioxidant Activities}

The antioxidant activities of aqueous extracts of $S$. latifolia after alginate elicitation were measured by ABTS radical scavenging and SOD-like activity. ABTS radical scavenging ability was calculated by $\mathrm{IC}_{50}$ value. The results ranged from $926.67 \pm 56.26$ to $4002.19 \pm 149.53 \mu \mathrm{g} \cdot \mathrm{mL}^{-1}$ (Figure 5a). SOD-like activity was measured by a colorimetric method and calculated by $\mathrm{IC}_{50}$ value. $\mathrm{IC}_{50}$ values of SOD-like activity ranged from $6.74 \pm 0.29$ to $18.70 \pm 0.57 \mathrm{mg} \cdot \mathrm{mL}^{-1}$ (Figure $5 \mathrm{~b}$ ). The highest ABTS radical scavenging and SOD-like activity were recorded with LF elicitor treated stalk and the lowest were from the fruit body of the control group. Similar to the TPC results, both fruit body and stalk samples of LF treatment exhibited higher antioxidant activities than the corresponding samples treated by SF elicitor. The results of antioxidant activities were significantly $(p<0.05)$ stimulated with the alginate elicitation.
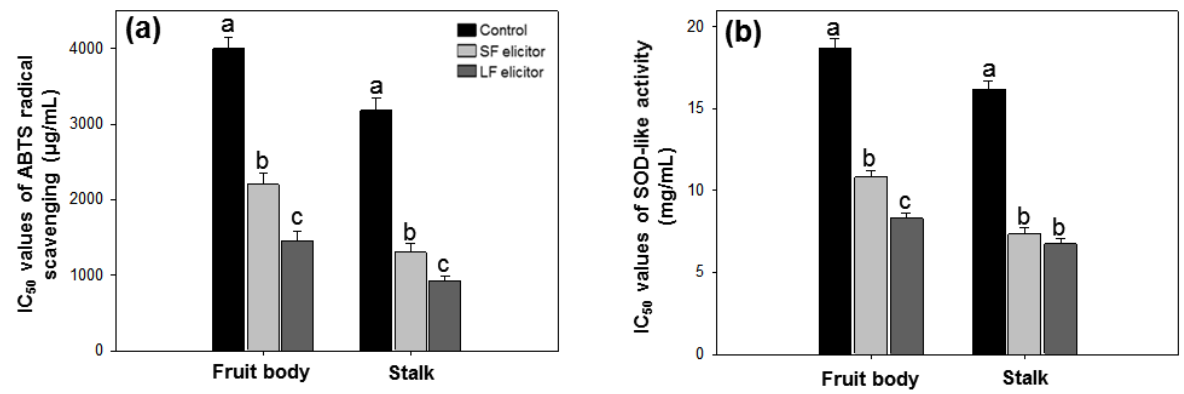

Figure 5. $\mathrm{IC}_{50}$ values of ABTS radical scavenging (a) and SOD-like activity (b) of aqueous extracts of Sparassis latifolia after alginate elicitation. SF: Solid fraction of Sargassum fusiforme; LF: Liquid fraction of S. horneri; Control: distilled water. The data were analyzed using analysis of variance (ANOVA) followed by Duncan's multiple-range test $(p<0.05)$ using SPSS software (SPSS, Chicago, IL, USA). Error bars indicate the mean \pm SD and different letters describe great differences within the same part of S. latifolia (fruit body and stalk).

\section{Discussion}

Sparassis species are widely used medicinal mushrooms in traditional Chinese medicine. However, despite its commercial potential, cultivation of S. latifolia has been limited to a few high-tech commercial farms because of its slow mycelial propagation into solid medium [42]. In addition, its slow rate of growth is a major obstacle to the employment of $S$. latifolia as a producer of $\beta$-glucan. Biotic or abiotic elicitors have been employed to enhance the production of $\beta$-glucan in S. latifolia. Ryoo et al. exploited the effects of physical stimulation of UV irradiation and temperature shock on $\beta$-glucan contents in S. latifolia and found that $\beta$-glucan yields reached $41.36 \pm 2.96 \%$ of flabella and $42.16 \pm 2.90 \%$ of stipe after UV irradiation for $10 \mathrm{~min}$ [22]. Park et al. utilized chitinase, $\beta$-glucuronidase, and lysing enzyme complex as elicitors to enhance the $\beta$-glucan content of $S$. latifolia and produced an increase in $\beta$-glucan concentration of $31 \%$, although the treatment caused a decrease in mushroom yield [23]. These results indicate that the elicitation technique needs to be evaluated for application in high-value mushroom cultivation.

This study aimed to increase the contents of $\beta$-glucan in S. latifolia through alginate elicitation, which was extracted from Sargassum species. Marine algae are an excellent biomass source used as a fertilizer for soil reformation because they are rich in carbohydrates and mineral content [43]. However, although Sargassum species contain a large amount of alginate and fucoidan, the high content of arsenic makes them unsuitable for consumption $[44,45]$. Polysaccharide-derived hydrocolloids in marine algae such as alginate, carrageenan, fucoidan, laminarin, ulvan, and glucuronan have been suggested as biotic elicitors to induce several different mechanisms including host defense mechanisms and growth enhancement in plant and fungi [46-49].

Alginate is the major structural polysaccharide of Sargassum species, consisting of MM, GG, and MG blocks arranged in various proportions in block units. The alginate $\mathrm{M} / \mathrm{G}$ ratio and yield may vary in accordance with the algae harvest season and geographical location [41]. Leal et al. studied 
block fractions of alginate in the brown algae Lessonia flavicans and Desmarestia ligulata [40]. The ethanol fraction obtained by partial acid hydrolysis of alginate was mainly composed of a heteropolymer block (MG). In addition, the solid fraction was rich in polymannuronic acid (MM) and the liquid fraction was rich in polyguluronic acid (GG) [28]. These were consistent with the results found in this study (see Table 2).

Alginate elicitors have been employed to modify cell metabolism in order to enhance the productivity of useful metabolites in plants and microorganisms [50]. The addition of chitosan, chitosan oligosaccharide, and alginate oligosaccharide to a culture of Panax ginseng C. A. Mey hairy roots caused growth inhibition and rises in total ginseng saponin accumulation with elicitor concentration [51]. Mannuronic acid of alginate may have a potent stimulatory effect on cytokine production, and it appeared to affect $\beta$-glucan content because of increased specific immunity owing to immunological effects [52]. In contrast, guluronic acid suppresses tissue damage caused by cytokines produced in response to inflammatory stimuli [53]. Our group investigated the supplement of sodium alginate to $S$. latifolia for the induced expression of $\gamma$-aminobutyric acid (GABA) both in the mycelia and fruiting bodies, which inhibited the dendrite outgrowth of excitatory neurons, but not that of inhibitory neurons [54]. Genome sequencing and genomics studies are underway to determine the underlying effect of alginate elicitors on $\beta$-glucan content of S. latifolia [55].

The effects of alginate elicitors on antioxidant activity and polyphenol synthesis in plants and microorganisms were also verified. Chitosan, pectin, and alginate promoted accumulation of phenolic acids, particularly 3-O-glucosyl-resveratrol, in Vitis vinifera, which was positively correlated with increased accumulation of anthocyanin [25]. Ulvan, carrageenan, alginate, and laminarin were examined for any elicitation effect in twigs of olive trees to elicit phenolic metabolism and control against Verticillium wilt of olive caused by V. dahlia, and the results showed increased phenylalanine ammonia-lyase (PAL) activity and total polyphenol content combined with the decline of wilt symptoms [27]. Sodium alginate extracted from Moroccan brown algae Fucus spiralis and Bifurcaria bifurcata was evaluated for elicitation on phenolic metabolism including PAL activity and total polyphenol content in seedling roots of date palm, and the results showed that PAL activity and phenolic compound content were stimulated with $1 \mathrm{mg} \cdot \mathrm{mL}^{-1}$ sodium alginate [26].

The present study suggested that treatment with Sargassum alginate exhibited elicitation effects on the growth and $\beta$-glucan contents in S. latifolia. Elicitors derived from algae alginate can be widely used in the cultivation process of other culinary and medicinal mushrooms.

\section{Conclusions}

Based on our results, the products of partial acid hydrolysis of alginate oligosaccharides could act as elicitors for stimulated growth of $S$. latifolia and production of useful metabolites such as $\beta$-glucan and polyphenols.

Author Contributions: Conceptualization and methodology, Y.-W.K. and H.-J.S.; formal analysis and investigation, Y.-W.K. and M.-H.C.; software and validation, Y.W. and J.L.; resources, M.-H.C.; data curation, Y.-W.K.; writing—original draft preparation, Y.-W.K.; writing—review and editing, Y.W.; supervision, H.-J.S.; project administration, H.-J.S.; funding acquisition, H.J.S. and J.L. All authors have read and agreed to the published version of the manuscript.

Funding: This research was funded by a National Research Foundation of Korea (NRF) grant funded by the Korean government, Grant No. NRF-2017R1A2B4006204; Shandong Provincial Key Research and Development Program (International Science and Technology Cooperation), Grant No. 2019GHZ033; and International Science and Technology Cooperation Program of Shandong Academy of Sciences, Grant No. 2019GHPY05.

Conflicts of Interest: The authors declare no conflict of interest. The funders had no role in the design of the study; in the collection, analyses, or interpretation of data; in the writing of the manuscript; or in the decision to publish the results. 


\section{References}

1. Roncero-Ramos, I.; Delgado-Andrade, C. The beneficial role of edible mushrooms in human health. Curr. Opin. Food Sci. 2017, 14, 122-128. [CrossRef]

2. Kimura, T. Natural products and biological activity of the pharmacologically active cauliflower mushroom Sparassis crispa. BioMed Res. Int. 2013, 2013, 982317. [CrossRef] [PubMed]

3. Ryoo, R.; Sou, H.D.; Ka, K.H.; Park, H. Phylogenetic relationships of Korean Sparassis latifolia based on morphological and its rDNA characteristics. J. Microbiol. 2013, 51, 43-48. [CrossRef] [PubMed]

4. Zhao, Q.; Feng, B.; Yang, Z.L.; Dai, Y.C.; Wang, Z.; Tolgor, B. New species and distinctive geographical divergences of the genus Sparassis (Basidiomycota): Evidence from morphological and molecular data. Mycol. Prog. 2013, 12, 445-454. [CrossRef]

5. Ryu, S.R.; Ka, K.H.; Park, H.; Bak, W.C.; Lee, B.H. Cultivation characteristics of Sparassis crispa strains using sawdust medium of Larix kaempferi. Korean J. Mycol. 2009, 37, 49-54. [CrossRef]

6. Chandrasekaran, G.; Oh, D.S.; Shin, H.J. Properties and potential applications of the culinary-medicinal cauliflower mushroom, Sparassis crispa Wulf.Fr. (Aphyllophoromycetideae): A review. Int. J. Med. Mushrooms 2011, 13, 177-183. [CrossRef]

7. Yoshikawa, K.; Kokudo, N.; Hashimoto, T.; Yamamoto, K.; Inose, T.; Kimura, T. Novel phthalide compounds from Sparassis crispa (Hanabiratake), Hanabiratakelide A-C, exhibiting anti-cancer related activity. Biol. Pharm. Bull. 2010, 33, 1355-1359. [CrossRef]

8. Bang, S.; Chae, H.S.; Lee, C.; Choi, H.G.; Ryu, J.; Li, W.; Lee, H.; Jeong, G.S.; Chin, Y.W.; Shim, S.H. New aromatic compounds from the fruiting body of Sparassis crispa (Wulf.) and their inhibitory activities on proprotein convertase subtilisin/kexin type 9 mRNA expression. J. Agric. Food Chem. 2017, 65, 6152-6157. [CrossRef]

9. Ruthes, A.C.; Smiderle, F.R.; Iacomini, M. D-Glucans from edible mushrooms: A review on the extraction, purification and chemical characterization approaches. Carbohyd. Polym. 2015, 117, 753-761. [CrossRef]

10. Synytsya, A.; Novák, M. Structural diversity of fungal glucans. Carbohyd. Polym. 2013, 92, $792-809$. [CrossRef] [PubMed]

11. Smiderle, F.R.; Alquini, G.; Tadra-Sfeir, M.Z.; Iacomini, M.; Wichers, H.J.; van Griensven, L.J. Agaricus bisporus and Agaricus brasiliensis $(1 \rightarrow 6)-\beta$-D-glucans show immunostimulatory activity on human THP-1 derived macrophages. Carbohyd. Polym. 2013, 94, 91-99. [CrossRef] [PubMed]

12. Morales, D.; Smiderle, F.R.; Villalva, M.; Abreu, H.; Rico, C.; Santoyo, S.; Iacomini, M.; Soler-Rivas, C. Testing the effect of combining innovative extraction technologies on the biological activities of obtained $\beta$-glucan-enriched fractions from Lentinula edodes. J. Funct. Foods 2019, 60, 103446. [CrossRef]

13. Chan, G.C.; Chan, W.K.; Sze, D.M. The effects of $\beta$-glucan on human immune and cancer cells. J. Hematol. Oncol. 2009, 2, 25. [CrossRef] [PubMed]

14. Ohno, N.; Miura, N.N.; Nakajima, M.; Yadomae, T. Antitumor 1,3- $\beta$-glucan from cultured fruit body of Sparassis crispa. Biol. Pharm. Bull. 2000, 23, 866-872. [CrossRef]

15. Harada, T.; Miura, N.N.; Adachi, Y.; Nakajima, M.; Yadomae, T.; Ohno, N. IFN- $\gamma$ induction by SCG, 1 , 3- $\beta$-D-glucan from Sparassis crispa, in DBA/2 mice in vitro. J. Interf. Cytok. Res. 2002, 22, 1227-1239. [CrossRef]

16. Harada, T.; Kawaminami, H.; Miura, N.N.; Adachi, Y.; Nakajima, M.; Yadomae, T.; Ohno, N. Comparison of the immunomodulating activities of 1,3- $\beta$-glucan fractions from the culinary-medicinal mushroom Sparassis crispa Wulf.: Fr. (Aphyllophoromycetideae). Int. J. Med. Mushrooms 2006, 8, 231-244. [CrossRef]

17. Tada, R.; Harada, T.; Nagi-Miura, N.; Adachi, Y.; Nakajima, M.; Yadomae, T.; Ohno, N. NMR characterization of the structure of a $\beta$-(1 $\rightarrow 3)$-D-glucan isolate from cultured fruit bodies of Sparassis crispa. Carbohyd. Res. 2007, 342, 2611-2618. [CrossRef]

18. Nameda, S.; Harada, T.; Miura, N.N.; Adachi, Y.; Yadomae, T.; Nakajima, M.; Ohno, N. Enhanced cytokine synthesis of leukocytes by a $\beta$-glucan preparation, SCG, extracted from a medicinal mushroom, Sparassis crispa. Immunopharm. Immunot. 2003, 25, 321-335. [CrossRef]

19. Park, H.G.; Shim, Y.Y.; Choi, S.O.; Park, W.M. New method development for nanoparticle extraction of water-soluble $\beta$-(1 $\rightarrow 3)$-D-glucan from edible mushrooms, Sparassis crispa and Phellinus linteus. J. Agric. Food Chem. 2009, 57, 2147-2154. [CrossRef] 
20. Narayani, M.; Srivastava, S. Elicitation: A stimulation of stress in in vitro plant cell/tissue cultures for enhancement of secondary metabolite production. Phytochem. Rev. 2017, 16, 1227-1252. [CrossRef]

21. Pettit, R.K. Small-molecule elicitation of microbial secondary metabolites. Microb. Biotechnol. 2011, 4, 471-478. [CrossRef] [PubMed]

22. Ryoo, R.; Sou, H.D.; Ka, K.H.; Park, H. Elicitor-induced $\beta$-glucan contents in fruit body of cauliflower mushroom (Sparassis latifolia). For. Sci. Technol. 2018, 14, 119-125. [CrossRef]

23. Park, H.; Ka, K.H.; Ryu, S.R. Enhancement of $\beta$-glucan content in the cultivation of cauliflower mushroom (Sparassis latifolia) by elicitation. Mycobiology 2014, 42, 41-45. [CrossRef] [PubMed]

24. Salachna, P.; Grzeszczuk, M.; Meller, E.; Soból, M. Oligo-alginate with low molecular mass improves growth and physiological activity of Eucomis autumnalis under salinity stress. Molecules 2018, 23, 812. [CrossRef]

25. Cai, Z.; Kastell, A.; Mewis, I.; Knorr, D.; Smetanska, I. Polysaccharide elicitors enhance anthocyanin and phenolic acid accumulation in cell suspension cultures of Vitis vinifera. Plant Cell Tissue Organ Cult. 2012, 108, 401-409. [CrossRef]

26. Bouissil, S.; Alaoui-Talibi, E.; Pierre, G.; Michaud, P.; El Modafar, C.; Delattre, C. Use of alginate extracted from Moroccan brown algae to stimulate natural defense in date palm roots. Molecules 2020, 25, 720. [CrossRef]

27. Ben Salah, I.; Aghrouss, S.; Douira, A.; Aissam, S.; El Alaoui-Talibi, Z.; Filali-Maltouf, A.; El Modafar, C. Seaweed polysaccharides as bio-elicitors of natural defenses in olive trees against verticillium wilt of olive. J. Plant Interact. 2018, 13, 248-255. [CrossRef]

28. Pawar, S.N.; Edgar, K.J. Alginate derivatization: A review of chemistry, properties and applications. Biomaterials 2012, 33, 3279-3305. [CrossRef]

29. Silva, T.H.; Alves, A.; Ferreira, B.M.; Oliveira, J.M.; Reys, L.L.; Ferreira, R.J.; Sousa, R.A.; Silva, S.S.; Mano, J.F.; Reis, R.L. Materials of marine origin: A review on polymers and ceramics of biomedical interest. Int. Mater. Rev. 2012, 57, 276-306. [CrossRef]

30. Davis, T.A.; Ramirez, M.; Mucci, A.; Larsen, B. Extraction, isolation and cadmium binding of alginate from Sargassum spp. J. Appl. Phycol. 2004, 16, 275-284. [CrossRef]

31. Asilonu, E.; Bucke, C.; Keshavarz, T. Enhancement of chrysogenin production in cultures of Penicillium chrysogenum by uronic acid oligosaccharides. Biotechnol. Lett. 2000, 22, 931-936. [CrossRef]

32. Alban, S.; Schauerte, A.; Franz, G. Anticoagulant sulfated polysaccharides. I. Synthesis and structure-activity relationships of new pullulan sulfates. Carbohyd. Polym. 2001, 47, 267-276. [CrossRef]

33. Grasdalen, H. High-field, ${ }^{1}$ H-n.m.r. spectroscopy of alginate: Sequential structure and linkage conformations. Carbohyd. Res. 1983, 118, 255-260. [CrossRef]

34. Manns, D.; Deutschle, A.L.; Saake, B.; Meyer, A.S. Methodology for quantitative determination of the carbohydrate composition of brown seaweeds (Laminariaceae). RSC Adv. 2014, 4, 25736-25746. [CrossRef]

35. McCleary, B.V.; Draga, A. Measurement of $\beta$-glucan in mushrooms and mycelial products. J. AOAC Int. 2016, 99, 364-373. [CrossRef]

36. Wootton-Beard, P.C.; Moran, A.; Ryan, L. Stability of the total antioxidant capacity and total polyphenol content of 23 commercially available vegetable juices before and after in vitro digestion measured by FRAP, DPPH, ABTS and Folin-Ciocalteu methods. Food Res. Int. 2011, 44, 217-224. [CrossRef]

37. Re, R.; Pellegrini, N.; Proteggente, A.; Pannala, A.; Yang, M.; Rice-Evans, C.A. Antioxidant activity applying an improved ABTS radical cation decolourising assay. Free Radic. Biol. Med. 1999, 26, 1231-1237. [CrossRef]

38. Odeyemi, S.; Dewar, J. Repression of acetaminophen-induced hepatotoxicity in HepG2 cells by polyphenolic compounds from Lauridia tetragona (L.f.) R.H. Archer. Molecules 2019, 24, 2118. [CrossRef]

39. Haug, A.; Larsen, B.; Smidsrød, O. Uronic acid sequence in alginate from different sources. Carbohyd. Res. 1974, 32, 217-225. [CrossRef]

40. Leal, D.; Matsuhiro, B.; Rossi, M.; Caruso, F. FT-IR spectra of alginic acid block fractions in three species of brown seaweeds. Carbohyd. Res. 2008, 343, 308-316. [CrossRef]

41. Fenoradosoa, T.A.; Ali, G.; Delattre, C.; Laroche, C.; Petit, E.; Wadouachi, A.; Michaud, P. Extraction and characterization of an alginate from the brown seaweed Sargassum turbinarioides Grunow. J. Appl. Phycol. 2010, 22, 131-137. [CrossRef]

42. Kim, S.R.; Kang, H.W.; Ro, H.S. Generation and evaluation of high $\beta$-glucan producing mutant strains of Sparassis crispa. Mycobiology 2013, 41, 159-163. [CrossRef] [PubMed]

43. Kumar, C.S.; Ganesan, P.; Suresh, P.V.; Bhaskar, N. Seaweeds as a source of nutritionally beneficial compounds-a review. J. Food Sci. Technol. 2008, 45, 1. 
44. Sinha, S.; Astani, A.; Ghosh, T.; Schnitzler, P.; Ray, B. Polysaccharides from Sargassum tenerrimum: Structural features, chemical modification and anti-viral activity. Phytochemistry 2010, 71, 235-242. [CrossRef] [PubMed]

45. Yokoi, K.; Konomi, A. Toxicity of so-called edible hijiki seaweed (Sargassum fusiforme) containing inorganic arsenic. Regul. Toxicol. Pharmacol. 2012, 63, 291-297. [CrossRef] [PubMed]

46. Bi, F.; Iqbal, S.; Arman, M.; Ali, A.; Hassan, M.U. Carrageenan as an elicitor of induced secondary metabolites and its effects on various growth characters of chickpea and maize plants. J. Saudi Chem. Soc. 2011, 15, 269-273. [CrossRef]

47. Chandía, N.P.; Matsuhiro, B. Characterization of a fucoidan from Lessonia vadosa (Phaeophyta) and its anticoagulant and elicitor properties. Int. J. Biol. Macromol. 2008, 42, 235-240. [CrossRef]

48. Aziz, A.; Poinssot, B.; Daire, X.; Adrian, M.; Bézier, A.; Lambert, B.; Joubert, J.M.; Pugin, A. Laminarin elicits defense responses in grapevine and induces protection against Botrytis cinerea and Plasmopara viticola. Mol. Plant Microbe Interact. 2003, 16, 1118-1128. [CrossRef]

49. El Modafar, C.; Elgadda, M.; El Boutachfaiti, R.; Abouraicha, E.; Zehhar, N.; Petit, E.; El Alaoui- Talibi, Z.; Courtois, B.; Courtois, J. Induction of natural defense accompanied by salicylic acid-dependant systemic acquired resistance in tomato seedlings in response to biloelicitors isolated from green algae. Sci. Hortic. 2012, 138, 55-63. [CrossRef]

50. Chandía, N.P.; Matsuhiro, B.; Mejías, E.; Moenne, A. Alginic acids in Lessonia vadosa: Partial hydrolysis and elicitor properties of the polymannuronic acid fraction. J. Appl. Phycol. 2004, 16, 127-133. [CrossRef]

51. Jeong, G.T.; Park, D.H.; Ryu, H.W.; Hwang, B.; Woo, J.C.; Kim, D.; Kim, S.W. Production of antioxidant compounds by culture of Panax ginseng C.A. Meyer hairy roots: I. Enhanced production of secondary metabolite in hairy root cultures by elicitation. Appl. Biochem. Biotechnol. 2005, 121, 1147-1157. [CrossRef]

52. Yamamoto, Y.; Kurachi, M.; Yamaguchi, K.; Oda, T. Stimulation of multiple cytokine production in mice by alginate oligosaccharides following intraperitoneal administration. Carbohyd. Res. 2007, 342, 1133-1137. [CrossRef] [PubMed]

53. Iwamoto, M.; Kurachi, M.; Nakashima, T.; Kim, D.; Yamaguchi, K.; Oda, T.; Iwamoto, Y.; Muramatsu, T. Structure-activity relationship of alginate oligosaccharides in the induction of cytokine production from RAW264. 7 cells. FEBS Lett. 2005, 579, 4423-4429. [CrossRef] [PubMed]

54. Choi, M.H.; Ki, S.; Lee, S.E.; Lee, G.; Shin, H.J. Enhanced GABA content from sodium alginate-induced Sparassis latifolia influences dendrite development in primary cortical neurons. J. Mushroom 2019, 17, 275-283.

55. Kiyama, R.; Furutani, Y.; Kawaguchi, K.; Nakanishi, T. Genome sequence of the cauliflower mushroom Sparassis crispa (Hanabiratake) and its association with beneficial usage. Sci. Rep. 2018, 8, 16053. [CrossRef] [PubMed]

(C) 2020 by the authors. Licensee MDPI, Basel, Switzerland. This article is an open access article distributed under the terms and conditions of the Creative Commons Attribution (CC BY) license (http://creativecommons.org/licenses/by/4.0/). 